\title{
An 11,000-year record of depositional environmental change based upon particulate organic matter and stable isotopes ( $C$ and $N$ ) in a lake sediment in southeastern Brazil
}

Article

Accepted Version

Creative Commons: Attribution-Noncommercial-No Derivative Works 4.0

Lorente, F. L., Pessenda, L. C. R., Oboh-Ikuenobe, A. A. B. J., de Fatima Rossetti, D., Giannini, P. C. F., Cohen, M. C. L., de Oliveira, P. E., Mayle, F. E., Francisquini, M. C. F., Bendassolli, J. A. and Macario, K. (2018) An 11,000-year record of depositional environmental change based upon particulate organic matter and stable isotopes ( $\mathrm{C}$ and $\mathrm{N}$ ) in a lake sediment in southeastern Brazil. Journal of South American Earth Sciences, 84. pp. 373-384. ISSN 0895-9811 doi: https://doi.org/10.1016/j.jsames.2018.04.006 Available at https://centaur.reading.ac.uk/81140/

It is advisable to refer to the publisher's version if you intend to cite from the work. See Guidance on citing.

To link to this article DOI: http://dx.doi.org/10.1016/j.jsames.2018.04.006 Publisher: Elsevier 
All outputs in CentAUR are protected by Intellectual Property Rights law, including copyright law. Copyright and IPR is retained by the creators or other copyright holders. Terms and conditions for use of this material are defined in the End User Agreement.

\section{www.reading.ac.uk/centaur}

\section{CentAUR}

Central Archive at the University of Reading

Reading's research outputs online 
1 An 11,000-year record of depositional environmental change based upon particulate 2 organic matter and stable isotopes ( $\mathrm{C}$ and $\mathrm{N})$ in a lake sediment in southeastern 3 Brazil

4

5 Flávio Lima Lorente ${ }^{\mathrm{a}^{*}}$, Luiz Carlos Ruiz Pessenda ${ }^{\mathrm{a}}$, Francisca Oboh-Ikuenobe ${ }^{\mathrm{b}}$, Antonio 6 Alvaro Buso Junior ${ }^{\mathrm{a}}$, Dilce de Fátima Rossetti ${ }^{\mathrm{c}}$, Paulo César Fonseca Giannini ${ }^{\mathrm{d}}$, Marcelo 7 Cancela Lisboa Cohen ${ }^{\mathrm{e}}$, Paulo Eduardo de Oliveira ${ }^{\mathrm{d}}$, Francis Edward Mayle ${ }^{\mathrm{f}}$, Mariah Izar 8 Francisquini $^{\mathrm{a}}$, Marlon Carlos França ${ }^{\mathrm{g}}$, José Albertino Bendassolli ${ }^{\mathrm{a}}$, Kita Macario ${ }^{\mathrm{g}}$ 9

${ }^{a}$ Center for Nuclear Energy in Agriculture (CENA), Piracicaba/SP, Brazil

${ }^{\mathrm{b}}$ Missouri University of Science and Technology, Rolla/MO, USA

${ }^{c}$ National Institute of Space Research, São José dos Campos/SP, Brazil

${ }^{d}$ University of São Paulo, São Paulo/SP, Brazil

$14 \quad{ }^{\mathrm{e}}$ Federal University of Pará, Belém/PA, Brazil

fUniversity of Reading, England

${ }^{\text {g}}$ Federal Institute of Pará, Belém/PA, Brazil

hFluminense Federal University, Niterói/RJ, Brazil

*Corresponding author at: Center for Nuclear Energy in Agriculture (CENA), Avenida Centenário, 303, CEP: 13416-000, Piracicaba, SP, Brazil. Tel: +55 19 34294742. E-mail address: flimalorente@yahoo.com.br 
1 Abstract

2

3 The aim of this paper is to reconstruct an 11,000-year history of depositional

4 environmental change in southeastern Brazil, based upon the integration of particulate

5 organic matter and stable isotope $(\mathrm{C}$ and $\mathrm{N})$ data from a 136- $\mathrm{cm}$ sediment core from Lake

6 Canto Grande. These proxies are used to explore the evolution of terrestrial and marine

7 influence on the lake. Isotopic $\left(\delta^{13} \mathrm{C}:-7.8 \%\right.$ to $-31.9 \% ; \delta^{15} \mathrm{~N}$ : $-0.07 \%$ to $4.9 \%$ ) and

8 elemental (total organic carbon - TOC: $0.58 \%$ to $37.19 \%$; total nitrogen - TN: $0.08 \%$ to

$91.73 \% ; \mathrm{C} / \mathrm{N}: 0.3$ to 54.7$)$ values recorded in Lake Canto Grande suggest that the sedimentary organic matter was derived from mostly $\mathrm{C}_{3}$ land plants and freshwater phytoplankton. Particulate organic matter and cluster analyses distinguished four associations characterized by the predominance of amorphous organic matter, followed by phytoclasts and palynomorphs. These results indicate two different phases of lake evolution. The first phase (136 - $65 \mathrm{~cm} ; \sim 10,943 \mathrm{cal}$ yr. B.P. to $\sim 8,529 \mathrm{cal}$ yr. B.P.) is recorded by sand layers interbedded with mud, which contain amorphous organic matter (AOM, 45-59\%) and phytoclasts (opaques - OP: 6-18\%; non-opaques - NOP: 17-23\%) which indicate a floodplain area. The second phase $(65-0 \mathrm{~cm} ; 8,529 \mathrm{cal}$ yr. B.P. to $\sim 662$ cal yr. B.P.) comprises mud, AOM (68-86\%) and palynomorphs (PAL, 8-16\%) related to lake establishment comparable to modern conditions. Thus, characterizing particulate organic matter, in combination with stable isotopes, proved to be invaluable proxies for lacustrine paleoenvironmental change through the Holocene.

Key words: Holocene; Organic matter; Stable isotopes; Paleoenvironment, Palynofacies 


\section{Introduction}

Brazilian lake systems are usually associated with river dynamics which have origins from a combination of erosional and sedimentation processes (Esteves 1988). The lower Doce River lake system is located in southeastern Brazil and considered as one of the most important freshwater system in the country. However, despite the importance of these lakes the studies about their evolution in the region are still scarce (Suguio and Kohler 1992; Rossetti et al. 2015).

According to Suguio and Kohler (1992), the lake system of the Doce River lower course, which includes the lake sampled for this study, was formed as a consequence of damming the Doce River course by marine and fluvial sediments. The Doce River valley was excavated during the last glacial maximum (21,000-18,000 years B.P.) and subsequently filled with river sediments (Suguio and Kohler, 1992). During the Holocene transgression $(\sim 5,000$ years B.P.) the main valley as well as the paleochannels of other tributaries, were inundated, forming a lagoonal-estuarine environment (Suguio and Kohler, 1992). Conversely, recent studies (Nascimento 2012; Buso Junior 2015) suggest that not all the lakes in the study area were influenced by Holocene sea level changes. The discrepancy is because paleoenvironmental reconstitution from lacustrine records in the region are mainly based on pollen profiles (Nascimento 2012; Buso Junior et al. 2013b; Buso Junior 2015) focusing on vegetation and climatic changes, but the depositional aspects and as the lakes evolved along the Holocene is not well known.

Lakes are dynamic systems and are subject to a variety of forcing variables that regulate the lake's history such as climate, vegetation, sea-level changes, tectonic activity and aquatic biota (Cohen 2003). Sediments can identify the source of organic matter in lacustrine sediments as an indicator of bio-geochemical processes during deposition and to infer environmental changes over time (Meyers and Lallier-Vergés 1999).

Sedimentary organic matter is an important record of past environmental changes. In this study qualitative and quantitative characterization of total organic matter (introduced by Combaz 1964 as palynofacies) combined with stable $\mathrm{C}$ and $\mathrm{N}$ isotopes are used to understand the sedimentological processes that govern the deposition and distribution of particulate organic matter in the lacustrine basin. As the studied lake is located in an important freshwater system, it is fundamental to investigate the lake history and consequently to provide information to better understand the whole system. 
Additionally, analyzing particulate organic matter serves as an important paleoenvironmental proxy for different types of biological, geological and environmental scientists, which makes it a multidisciplinary method (Tyson 1995). It enables the identification of individual particulate components, as well as the determination of absolute and relative proportions, including their sizes and state of preservation (Tyson 1995; Batten 1996). Particulate organic matter analysis informs depositional facies, hydrodynamic, river inflow, sea-level variations and lakes evolution. The greatest advantage of its application is the possible integration with palynology, sedimentology and stable isotope analysis (Menezes et al. 2008).

Although particulate organic matter analysis is usually applied in studies that focus on basins with hydrocarbon-generating (oil and gas) potential, this proxy has been on the rise in Quaternary studies in order to better understand the composition of sedimentary organic matter (Meyer et al. 2005; Silva et al. 2010; Boussafir et al. 2012; Zocatelli et al. 2012; Gadens-Marcon et al. 2014; Lorente et al. 2014). The method can provide important new insights into past environments when integrated with stable $\mathrm{C}$ and $\mathrm{N}$ isotopes. However, paleoenvironmental inferences based solely upon isotopic data from organic matter in lake sediments may be inconclusive, such isotopic data are best interpreted in the context of other paleoenvironmental proxies.

Paleoenvironmental investigations are commonly based only on microfossils or geochemical data such as stable isotopes, but studies integrating different proxies are incipient. To demonstrate the potential of particulate organic matter in Quaternary studies, this study integrates this proxy, stable isotopes ( $\mathrm{C}$ and $\mathrm{N})$, grain size and radiocarbon date of sediment of Lake Canto Grande to understand its evolution during the Holocene and consequently to provide new information about the history of lake system of the Doce River lower course. These data were compared to the lake evolution to explore marine influence in the sedimentary deposit due to Holocene sea level changes.

\subsection{Study site}

The Espírito Santo Basin is a sedimentary basin with a tectono-sedimentary history related to the breakup of the Gondwana and the consequent opening of the South Atlantic Ocean in the late Jurassic and early Cretaceous period (Vieira et al. 1994). This basin extends under the current coastal plain, continental shelf and slope of eastern Brazil, in the State of Espírito Santo. The Pleistocene and Holocene sediments of the Espírito 
1 Santo Basin were formed in marine terraces, as well as fluvio-marine, lagoon and eolian environments. The coastal plain is associated with the Doce River, and its evolution has been strongly controlled by relative sea-level changes, fluvial sedimentary supply, long shore drifts and changes in the atmospheric circulation (Martin et al. 1993).

Lake Canto Grande $\left(19^{\circ} 16^{\prime} 01,4^{\prime \prime} \mathrm{S} / 39^{\circ} 56^{\prime} 41,9^{\prime \prime} \mathrm{W}\right)$ is located in the northern region of the state of Espírito Santo (Fig. 1). The lake is a 3-meter deep and its water level is about 5-meter above mean sea level. The northern of Espírito Santo state is characterized by a highland area with Precambrian rocks in the western portion, a plateau of continental Neogene deposits, and a coastal plain with Quaternary sediments accumulated along the coastline (Suguio et al. 1982). The Lake Canto Grande is situated at the contact between the Neogene plateau and the Pleistocene beach ridges, and currently has sediment inflows from small drainage channels.

The climate in the region is classified as Aw based on the Köppen system (Köppen 1948), i.e., humid tropical with dry winters and rainy summers. The mean annual temperature is $23^{\circ} \mathrm{C}$, and the mean annual precipitation is $1,215 \mathrm{~mm}$ (Buso Junior et al. 2013a). The vegetation is dominated by Atlantic forest (Tabuleiros forest) and grasslands in areas closer to the lake (IBGE 1987). The modern vegetation in the lake margins has been degraded by human activities as housing and tourism.

\section{Material and methods}

\subsection{Sampling}

A 136-cm long sediment core (LCG-B) was recovered from the bottom in the center of Lake Canto Grande using a modified (drop-hammer) Livingstone piston sampler on a floating platform (Livingstone 1955; Colinvaux et al. 1999). LCG-B core was transported to the ${ }^{14} \mathrm{C}$ Laboratory at the Center for Nuclear Energy in Agriculture at the University of São Paulo (CENA-USP). Samples were collected at intervals of up to 10 $\mathrm{cm}$ for particulate organic matter and grain size analyses, and at $2 \mathrm{~cm}$ intervals for isotope (carbon and nitrogen) analyses.

\subsection{Radiocarbon dating and grain size}


${ }^{14} \mathrm{C}$ analyses of 10 sediment samples were carried out by Accelerator Mass Spectrometry (AMS) at the Center for Applied Isotope Studies (CAIS) at the University of Georgia (USA) and at the Radiocarbon Laboratory at the Fluminense Federal University (Brazil). Radiocarbon ages were expressed as conventional ${ }^{14} \mathrm{C}$ yr. B.P. (years Before Present) normalized to a $\delta^{13} \mathrm{C}$ of $-25 \%$ VPDB and in cal yr. B.P. (calibrated years Before Present), with precision of $2 \sigma$ (Reimer et al. 2009). Mean calibrated ages were used in the text for discussing the data.

Grain size distribution of 14 samples were determined by laser diffraction analysis. Sediment samples were processed using $\mathrm{H}_{2} \mathrm{O}_{2}$ to eliminate organic matter and $\mathrm{HCl}$ to eliminate carbonates. Results were converted into statistical values obtained by the SysGran program (Camargo 1999) and the grain size distribution were divided into sand $(2-0.0625 \mathrm{~mm})$, silt $(62.5-3.9 \mu \mathrm{m})$ and clay $(3.9-0.12 \mu \mathrm{m})$, following Wentworth (1922).

\subsection{Particulate organic matter}

Analyses of particulate organic matter was based on 14 samples, with $5 \mathrm{~g}$ of bulk sediment for each sample being processed following non-oxidative palynological standard procedures (Tyson 1995; Mendonça-Filho 1999). The samples were washed with $\mathrm{HCl}$ and $\mathrm{HF}$ to remove the mineral matrix and $\mathrm{ZnCl}_{2}$ to separate the organic matter. For each sample, a total of 500 organic matter particles were counted under white light microscopy at 400x magnification. The particulate organic matter classification was adapted from the model proposed by Tyson (1995) and Mendonça-Filho (1999). Percentage calculations and cluster analysis by similarity index were undertaken using the TILIA software package (Grimm 1987). Classification of particulate organic matter was as detailed as possible, taking into account aspects such as biological origin of particles, ecological significance of the groups, preservation state and morphology variations. In this context, the organic matter components were divided into three main groups:

(1) AOM: derived from bacteria, phytoplankton and/or degraded organic aggregates. Particles are dispersed or occur as lumps that are structureless and have irregular shape.

(2) Phytoclasts: derived from the ligno-cellulosic tissues of higher plants and/or fungi. Plant tissues may have preserved cellular structures such as stomata and are 
usually classified as 'non-opaque' (un-biostructured, biostructured, cuticles, membranes and fungi hyphae) which are yellow, brown or dark brown particles, and 'opaque (equidimensionals, elongates and corroded) particles' that are also described as charcoal.

(3) Palynomorphs: all components with organic walls resistant to acid attack, such as sporomorphs (pollen grains and spores), freshwater phytoplankton (Botryococcus braunii and other algae), marine phytoplankton (dinoflagellate cysts), foraminiferal test linings, fungal spores and zooclasts (buccal fragments of arthropods and worms (Platyhelminthes) eggs and other animal remains). Pollen grains were divided into colporate, colpates, porates and grains derived from mangroves. Triletes and monoletes (ornamented and not ornamented) comprise Pteridophyte spores.

\subsection{Elemental $(\mathrm{C}$ and $\mathrm{N})$ and isotopic $\left(\delta^{13} \mathrm{C}\right.$ and $\left.\delta^{15} \mathrm{~N}\right)$ analyses}

Isotopic analyses were made on natural and decarbonated samples in order to verify the amount of inorganic carbon. No difference was noted, thus the original 62 bulk samples were washed with distilled water and plant remains were physically removed. Total organic carbon (TOC), total nitrogen (TN), and $\delta^{13} \mathrm{C}$ and $\delta^{15} \mathrm{~N}$ were analyzed by isotope ratio mass spectrometry and elemental analysis at the Stable Isotope Laboratory of CENA at the University of São Paulo (USP). TOC and TN values were expressed in percentage by dry weight, while ${ }^{13} \mathrm{C}$ and ${ }^{15} \mathrm{~N}$ were expressed with respect to the standards VPDB and $\mathrm{N}_{2}$ respectively, with a precision of $\pm 0.2 \%$. Elemental results were used to calculate the $\mathrm{C} / \mathrm{N}$ (weight/weight) for the sediment samples.

The use of stable isotopes in environmental studies is based on variations in different compartments of an ecosystem, expressed by the ratio between rare and more abundant isotopes (Boutton 1996). In general, $\delta^{13} \mathrm{C}$ values of $\mathrm{C}_{3}$ (trees, shrubs and some grasses) and $\mathrm{C}_{4}$ (savanna grasses) land plants are between $-32 \%$ to $-22 \%$ and $-17 \%$ to 9\%, respectively (Meyers 1997). In lake systems, isotopic analysis enables differentiation between $\mathrm{C}_{3}$ versus $\mathrm{C}_{4}$ land plants as primary sources of organic matter (Meyers and Lallier-Vergès 1999), which cannot be verified using only pollen analysis that is limited by taxonomic resolution of the grass family. In addition, autochthonous organic matter (phytoplankton and bacteria) within a lake is characterized by low $\mathrm{C} / \mathrm{N}$ ratios $(<10)$ and $\delta^{15} \mathrm{~N}$ values around $+8.5 \%$, whereas allochthonous organic matter (vascular plants from 
1 the lake catchment) is generally characterized by $\mathrm{C} / \mathrm{N}$ ratios higher than 20 and $\delta^{15} \mathrm{~N}$ of $2+0.5 \%$ (Meyers 1997).

3

4

3. Results

5

$6 \quad$ 3.1. Lithology, grain size and ${ }^{14} \mathrm{C}$ ages

7

8

9

10

11

The Lake Canto Grande core is rich in organic matter and it is comprised mainly of mud and sand (Fig. 2). Sedimentary characteristics were used to define six lithofacies at the following depth intervals: (1) 136-99 cm, with fine sand interbedded with dark gray silt layers (sand: $\pm 93.4 \%$; silt: $\pm 5.24 \%$; clay: $\pm 1.2 \%$ ); (2) $99-86 \mathrm{~cm}$, with fine sand and black silt with micro sand lenses (sand: $\pm 94.2 \%$; silt: $\pm 5.7 \%$; clay: $\pm 0.02 \%$ ); (3) 80-63 cm, with black clayey silt (sand: $\pm 10.1 \%$; silt: $\pm 64.2 \%$; clay: $\pm 25.5 \%$ ) ; (4) $63-50 \mathrm{~cm}$, with dark gray clayey silt (sand: $\pm 0.8 \%$; silt: $\pm 70.3 \%$; clay: $\pm 28.7 \%$ ); (5) $50-27 \mathrm{~cm}$, with massive light gray clayey silt (sand: $0 \%$; silt: $\pm 67 \%$; clay: $\pm 33 \%$ ); and (6) $27-0 \mathrm{~cm}$, with organic black peat (sand: $\pm 0.4 \%$; silt: $\pm 72.7 \%$; clay: $\pm 26.8 \%$ ). The interval between 86 and $80 \mathrm{~cm}$ was lost during sampling.

Ten radiocarbon dates indicate a progressive downward age increase (Table 1). Sequential ages ranged from $\sim 10,943 \mathrm{cal}$ yr. B.P. $133 \mathrm{~cm}$ depth to $\sim 662 \mathrm{cal} \mathrm{yr}$. B.P. at 3 $\mathrm{cm}$ depth. The sedimentation rates ranged from 0.002 to $0.36 \mathrm{~cm} /$ year.

\subsection{Organic geochemistry}

The total organic carbon (TOC) content ranged from $0.58 \%(136-134 \mathrm{~cm})$ to $37.19 \%(72-70 \mathrm{~cm})$. The total nitrogen $(\mathrm{TN})$ ranged from $0.08 \%(102-100 \mathrm{~cm})$ to $1.73 \%$ (136-134 cm), resulting in $\mathrm{C} / \mathrm{N}$ ratios (weight/weight) of 0.3 at $136-134 \mathrm{~cm}$ depth and 54.66 at $50-48 \mathrm{~cm}$ depth. The isotopic values varied from $-7.87 \%$ o $(68-66 \mathrm{~cm})$ to $-31.89 \%$ o $\left(22-20 \mathrm{~cm}\right.$ ) for $\delta^{13} \mathrm{C}$, and from $-0.07 \%$ to $4.9 \%$ for $\delta^{15} \mathrm{~N}$. The organic geochemistry data are indicated in Figure 3.

\subsection{Characterization of particulate organic matter and resulting associations}


Four associations were identified from cluster analysis generated by similarity index of the particulate organic matter components (Fig. 4). The details of each association are described in the following.

\section{Association 1}

Association 1 (136-85 cm; $\sim 10,943$ cal yr. B.P. to $\sim 10,322$ cal yr. B.P. interpolated age) was characterized by the predominance of AOM $( \pm 53 \%)$ and nonopaque phytoclasts ( $\pm 19 \%)$, followed by opaque phytoclasts and palynomorphs, with an average of $13 \%$ each. Among the non-opaque subgroup, cuticles $( \pm 7.5 \%)$ and unbiostructured $( \pm 5.8 \%)$ were common. Biostructured striped non-opaque $( \pm 3.5 \%)$ and fungal hyphae $( \pm 2.1 \%)$ were recorded as subordinate elements. Percentages of biostructured perforated non-opaque phytoclasts did not exceed $1 \%$.

The main components of opaque phytoclasts were the biostructured particles $( \pm 4.7 \%)$, followed by elongated $( \pm 4 \%)$, equidimensionals $( \pm 2.5 \%)$ and partly degraded clasts $( \pm 2.6 \%)$. Considering the palynomorphs group, fungal spores, colporate and porate pollen grains were common, averaging $5.4 \%, 3.2 \%$ and $2.3 \%$, respectively. Pteridophyte spores, freshwater algae, colonies of Botryococcus braunii and zooclasts occurred with average relative abundances not exceeding $1 \%$.

\section{Association 2}

AOM $( \pm 57.6 \%)$ was the dominant component in this association $(85-65 \mathrm{~cm}$; $\sim 10,322$ cal yr. B.P. - interpolated age to $\sim 8,529$ cal yr. B.P.). Non-opaque $( \pm 22.7 \%)$ and opaque $( \pm 13.4 \%)$ phytoclasts, and palynomorphs $( \pm 6.3 \%)$ comprised this association as well. Cuticles remained prevalent in the non-opaque subgroup, with an average percentage of $12 \%$. Un-biostructured $( \pm 6 \%)$ and biostructured striped non-opaque phytoclasts $( \pm 3.6 \%)$ were well represented. Fungal hyphae had lower percentages $( \pm 1 \%)$ compared to association 1. Biostructured perforated non-opaque phytoclasts were not recorded.

The opaque phytoclasts subgroup was dominated by elongated and biostructured clasts, averaging $5.2 \%$ and $4.7 \%$, respectively. The amount of equidimensionals $( \pm 2 \%)$ and corroded $( \pm 1.6 \%)$ opaque phytoclasts was lower than in association 1. Fungal spores $( \pm 2.8 \%)$ and colporate pollen grains $( \pm 1.6 \%)$ remained dominant in the palynomorphs 
1

group. Porate pollen grains, Pteridophyte spores, freshwater algae, Botryococcus braunii colonies and zooclasts comprised this association, but with percentages not exceeding $1 \%$.

\section{Association 3}

Association 3 (65 to $23 \mathrm{~cm} ; 8,529$ cal yr. B.P. to $\sim 1,786$ cal yr. B.P.) was dominated by $\mathrm{AOM}( \pm 79 \%)$. It also consisted of palynomorphs $( \pm 12.2 \%)$, non-opaque phytoclasts $( \pm 5.3 \%)$ and opaque phytoclasts $( \pm 3.2 \%)$. Non-opaque phytoclasts had their lowest values throughout the sedimentary succession. Palynomorphs included mainly colporate pollen grains $( \pm 5.2 \%)$, Botryococcus braunii colonies $( \pm 2.9 \%)$ and porate pollen grains $( \pm 1.5 \%)$. Values of fungal spores $( \pm 1.2 \%)$ were lower than in associations 1 and 2. Although the values for freshwater algae did not exceed $1 \%$, it was an increase compared to association 2. Pteridophyte spores, colpate pollen grains and zooclasts occurred sparsely.

The main components of the non-opaque phytoclasts subgroup were un-structured phytoclasts $( \pm 2.5 \%)$ and cuticles $( \pm 2.1 \%)$. Biostructured striped and perforated nonopaque phytoclasts and fungal hyphae averaged up to $0.5 \%$ each. Opaque phytoclasts were equidimensionals $( \pm 1.2 \%)$, elongated $( \pm 1.1 \%)$, biostructured $( \pm 0.5 \%)$ and corroded $( \pm 0.4 \%)$.

\section{Association 4}

Association 4 (23-0 cm; $\sim 1,786 \mathrm{cal}$ yr. B.P. to $\sim 662 \mathrm{cal}$ yr. B.P.) consisted of the following groups: AOM $( \pm 75.2 \%)$, palynomorphs $( \pm 13 \%)$, non-opaque phytoclasts $( \pm 9 \%)$ and opaque phytoclasts $( \pm 2.8 \%)$. The palynomorphs group was characterized by the predominance of colonies of Botryococcus braunii $( \pm 6.7 \%)$ which had their highest values of the whole sedimentary profile. In addition, colporate $( \pm 3.2 \%)$ and porate pollen grains $( \pm 1.4 \%)$ were also recorded as prominent particles. Pteridophyte spores, fungal spores, colpate pollen grains, freshwater algae (except $B$. braunii) and zooclasts were less than $0.5 \%$. In the non-opaque phytoclasts subgroup, un-structured particles $( \pm 4.7 \%)$ and cuticles $( \pm 3.2 \%)$ were predominant, followed by fungal hyphae $( \pm 0.6 \%)$, biostructured striped and perforated non-opaque phytoclasts averaging $0.1 \%$ each. 
Among the opaque phytoclasts subgroup, equidimensionals particles $( \pm 1.4 \%)$ were prevalent, whereas elongated $( \pm 0.8 \%)$, biostructured $( \pm 0.4 \%)$, and corroded $( \pm 0.2 \%)$ phytoclasts were subordinated. This association had the lowest values recorded for the opaque phytoclasts.

\section{Discussion}

\section{1. $\delta^{13} \mathrm{C}$ vs. $\mathrm{C} / \mathrm{N}$}

The integrated results allow the recognition of two phases (Phase 1: 136-65 cm, $\sim 10,943$ cal yr. B.P. to $\sim 8,529$ cal yr. B.P.; Phase 2: $65-0 \mathrm{~cm}, \sim 8,529 \mathrm{cal}$ yr. B.P. to $\sim 662$ cal yr. B.P.) in the depositional environment in the Lake Canto Grande deposits. In general, the isotopic and elemental values recorded in the studied core indicate a mixture in the sources of sedimentary organic matter, with contribution of $\mathrm{C}_{3}$ vascular plants and freshwater phytoplankton (Fig. 5). According to Talbot and Johannessen (1992), organic matter produced from atmospheric $\mathrm{CO}_{2}$ absorbed by $\mathrm{C}_{3}$ vascular plants has $\delta^{13} \mathrm{C}$ values in the range $-25 \%$ to $-35 \%$. These are comparable to the mean $\delta^{13} \mathrm{C}$ values of $-30 \%$ o $(\sigma$ : $2.5 \%$ ) recorded for the phase 1 , and $-28 \%$ ( $\sigma: 0.7 \%$ o for the phase 2 . Moreover, the sources of organic matter can also be distinguished by $\delta^{15} \mathrm{~N}$ values (algae: $+8.5 \%$, vascular plants: $+1 \%$; Meyers 1997). The average for $\delta^{15} \mathrm{~N}$ values described was $1.5 \%$ $(\sigma: 1.2 \%$ ) and 3\%o ( $\sigma: 2.9 \%$ ) for the phase 1 and 2 , respectively. These data are compatible with the predominance of terrestrial source in both phases, but a phytoplankton increase in the phase 2 may have occurred. However, $\delta^{15} \mathrm{~N}$ data should be used cautiously, since $\delta^{15} \mathrm{~N}$ signal can be poorly recorded by sediments and isotope shifts are highly variable (Lehmann et al. 2002).

Additionally the $\delta^{13} \mathrm{C}$ vs. $\mathrm{C} / \mathrm{N}$ binary diagram (Fig. 5) suggests $\mathrm{C}_{3}$ land plants influence in phase 1 , whereas the trend for phase 2 indicates a freshwater phytoplankton input, which can be correlative with particulate organic matter data presented in the following section.

\subsection{Paleoenvironmental evolution}

Phase 1: floodplain (136-65 cm; 10,943 cal yr. B.P. to $\sim 8,529$ cal yr. B.P.) 
This phase was defined by associations 1 and 2 and was characterized by AOM as the main particulate organic matter component (Fig. 6). AOM usually dominates in reducing environments and distally from source areas, where there is low terrestrial input (Tyson 1995). The predominance of this group may indicate that the organic matter was deposited in anoxic-dysoxic conditions at the water-sediment interface in response to a low-energy environment. Once the AOM is kept in suspension and deposited with silt and clay, and high percentages of this group could be related to an environment of few variations in the hydrodynamic conditions. However, the interval between 135 and $86 \mathrm{~cm}$ was mainly comprised of fine sand and the highest values of phytoclasts (non-opaques and opaques), which may be indicative of river influence, once they are transported in their majority by rivers (Tyson 1995).

Non-opaque phytoclasts (NOP) can suggest oxic conditions, proximity to the river source, or terrestrial sediment input through floods (Tyson 1995). Among this subgroup, cuticles and un-biostructured non-opaque phytoclasts are prevalent in deposits formed during phase 1 (Fig 4). Since cutin has been considered as the most resistant substance produced by plants, cuticles are resistant to aquatic environments (Tyson 1995). According to Batten (1996), most cuticles identified in palynological slides are derived from leaves, and are generally associated with fluvial-deltaic environments of low energy, from where they can be transported over long distances prior to destruction or deposition. However, the cuticles identified in this core are well preserved, suggesting that their deposition most likely occurred near the source area, as described by Mendonça-Filho et al. (2010) for a Cenozoic basin in Southern Brazil.

Un-biostructured phytoclasts, identified in some studies (Sebag et al. 2006a; 2006b; Boussafir et al. 2012; Zocatelli et al. 2012) as gellified particles, have their origin related to plant tissue degradation in aquatic environments, such as lakes, or under anaerobic conditions, such as in hydromorphic (excess water) soils (Sebag et al. 2006a). Biostructured phytoclasts are described as originating from local vegetation (Tyson 1995), but they can also be deposited in river channels during flooding (Batten 1996). The abundance of fungal spores in deposits formed during phase 1 may also be related to temporary flooding, as also recorded along banks of rivers and streams elsewhere (Grill et al. 2007).

The amount of opaque phytoclasts gradually increases in aquatic environments, as they are deposited distally from source areas (Sebag et al. 2006a). Opaque phytoclasts are the most resistant components in the particulate organic matter and are usually linked 
to coarse sediments in high-energy environments (Oboh 1992; Tyson 1995). They may also be formed by oxidation, such as occurs in conditions of seasonal fluctuations of the water column and exposure of particles to oxygenation (Tyson 1995). Alternatively, they indicate the occurrence of fires near the depositional environment, since biostructured particles, also known as charcoal, originate from the combustion of plant tissues (Batten 1996).

Particulate organic matter data suggested that the deposits of this phase in the Lake Canto Grande core may have been formed in a floodplain (Fig. 8). This is an area of low relief and subjected to periodic flooding (Scherer 2008) along alluvial valleys (Bridge 2006). Floodplains are typically composed of different proportions of sand, silt and clay (Wolman and Leopold 1957), which are transported as bottom sediments or suspended load during flooding (Bridge 2006).

According to Sebag et al. (2006b), all constituents of the particulate organic matter are present in marshes but have different relative abundances. In aquatic environments, autochthonous elements (AOM and algae) are predominant, while allochthonous fractions (phytoclasts) are moderately preserved (Sebag et al. 2006b). Sedimentary samples with TOC values lower than $2-3 \%$ are usually associated with assemblages dominated by phytoclasts where these values are determined by variations in the abundance of vegetal particles. On the other hand, sediment samples with TOC values higher than 3\% are dominated by amorphous organic matter (Mendonça-Filho et al. 2010). The TOC values recorded for the floodplain depositional phase are between $0.5 \%$ and $37 \%$ (Fig. 3), which reflect the mixture of components of particulate organic matter. Noteworthy are the high values of TOC (23-37\%) between 78 and $64 \mathrm{~cm}$ (Fig. 3). According to Mendonça-Filho et al. (2010), such values in sediments may indicate low organic decomposition and high concentration of plant material from terrestrial origin, possibly due to peat formation. Therefore, the predominance of amorphous organic matter and total organic carbon in deposits of phase 1 of Lake Canto Grande records a periodically flooded low energy environment with high content of phytoclasts sourced mostly from the surrounding vegetation.

Nascimento (2012) presented palynological data from Lake Durão, located $3 \mathrm{~km}$ to the north of Lake Canto Grande, to infer a lake system with a strong fluvial influence and contributions of terrigenous input during the Early Holocene ( 6,000 cal yr. B.P.). A shallow, temporary lake with periodic flooding was inferred from low percentages of freshwater algae. A palynological study by Buso Junior (2015) of the LCG-B core from 
1 Lake Canto Grande revealed pollen of Calophyllum (Clusiaceae), Croton 2 (Euphorbiaceae) and Symphonia (Clusiaceae), especially for the period between $~ 10,000$ and $\sim 8,500$ cal years B.P. These genera likely feature periodically in flooded forest vegetation (Buso Junior 2015), which corroborates the particulate organic matter data.

According to Buso Junior (2015), the Atlantic forest (Tabuleiros forest) probably was not present around the Lake Canto Grande between 11,000 and 7700 cal years BP as a consequence of a relatively dry period (less humid), which is in agreement with studies in southeastern Brazil (Pessenda et al. 2004). The relatively dry period for the Early Holocene in the north of Espírito Santo State probably influenced the alluvial processes and the sedimentation of sand-rich sediments. In the Doce River Middle Valley lake system, typical lacustrine sediments were only identified after 8000 years BP, and before that the lakes should have been shallow and influenced by alluvial processes (Mello et al. 1999). Lake Canto Grande evolution can be considered similar to the proposed for Doce River Middle Valley lakes. Higher percentage of phytoclasts in particulate organic matter corroborates the river influence.

Although abundance of Botryococcus braunii colonies and other freshwater algae is low during floodplain deposition in the Lake Canto Grande area (Fig. 4), C/N values of 2-4 between 136 and $104 \mathrm{~cm}$ depth (Fig. 3) point to a predominantly algal/microbial carbon source (vascular plants have $\mathrm{C} / \mathrm{N}$ ratios > 20) (Meyers, 1997), in contrast to the particulate organic matter data. One hypothesis to explain the low $\mathrm{C} / \mathrm{N}$ ratios at this stage is the presence of bacteria in the depositional environment (Fig. 5). Decomposition of phytodetritus by bacteria is a mechanism for $\mathrm{N}$-enriched organic matter (Ruttenberg and Goñi 1997). According to Ogrinc et al. (2005), low C/N values could reflect the presence of bacterial biomass or substances derived from bacteria. Amorphous organic material is predominant in this interval and it may have been derived from degradation of phytoplankton or bacteria, or even reworking of the organic matter by heterotrophic bacteria and products of bacterial activity (Tyson 1995; Mendonça-Filho et al. 2010). Grill et al. (2002) also recorded AOM originating from terrestrial material degraded by bacterial activity in fluvial deposits of meandering rivers in Argentina.

However, $\mathrm{C} / \mathrm{N}$ ratios in sediments may provide erroneous information on the origin of organic matter in certain situations. According to Meyers (2003), most of the elemental analyses of $\mathrm{C}$ and $\mathrm{N}$ are carried out after removal of carbonate. However, the residual values of total nitrogen encompass organic and inorganic fractions. In sediments with low concentrations of organic matter (TOC $<0.3 \%$ ), the proportion of inorganic 
1 nitrogen can be higher than the organic fraction, which would result in artificially lower

$2 \mathrm{C} / \mathrm{N}$ ratios. Nonetheless, in this study the graphic of TOC vs. TN (Fig. 7) shows two

3 distinct distributions that correspond to the intervals $135-105 \mathrm{~cm}$ and 103-top. These

4 distributions correlate with TOC and TN values. The extrapolation of the linear regression

5 indicates that the TN in the Lake Canto Grande core is from organic origin.

Moreira et al. (2013) performed elemental and isotopic analyses ( $\mathrm{C}$ and $\mathrm{N})$ on a core sampled near the Amazon River and recorded low values for TOC $(0.3 \%), \mathrm{C} / \mathrm{N}(\sim 5)$, and $\delta^{15} \mathrm{~N}$ (ca. 3\%o). These geochemical data are consistent with an intermittent lake with phytoplankton production during periods of flooding and high levels of organic matter degradation during periods of drought. Moreira-Turcq et al. (2013) reported C/N ratios of POM as low as $\sim 5$ in the total suspended sediments, and $\mathrm{C} / \mathrm{N}$ values in superficial sediment as low as 7, at the Curuai floodplain, Amazon River. These data suggest that extensive phytoplankton blooms, dominated by cyanobacteria, in the lake floodplain, may be responsible for this low $\mathrm{C} / \mathrm{N}$ characteristic of the organic matter. Between 104 and 65 $\mathrm{cm}, \mathrm{C} / \mathrm{N}$ values varied from 22 to 49 , reflecting the predominance of terrestrial plants as the source of sedimentary organic matter, a trend observed up to the top of the profile (Fig. 3). Therefore, the increase of $\mathrm{C} / \mathrm{N}$ values could indicate a more dense vegetation in the area and terrestrial higher plant allochthonous carbon.

Phase 2: lake (65-0 cm; 8,529 cal yr. B.P. to 662 cal yr. B.P.)

Phase 2 was represented by associations 3 and 4, which were dominated by silt and clay with AOM and PAL (Fig. 6). The percentage of AOM is generally higher in sedimentary facies rich in these grain sizes due to hydrodynamic factors, distance of fluvial-deltaic areas, as well as low abundance of phytoclasts and palynomorphs (Tyson 1995). The prevalence of fine-grained sediments in Lake Canto Grande is in agreement with the predominance of amorphous group. Thus, the recorded AOM values probably indicate that the organic matter was deposited in a low turbulence environment with anoxic-dysoxic conditions prevailing in the sediment-water interface. Furthermore, increasing TOC values (4-11\%) toward the top of the sedimentary profile (Fig. 3) may be indicative of reducing conditions and better preservation of organic matter.

Silva et al. (2010) analyzed the particulate organic matter in samples from Lake Preta in the state of Minas Gerais and identified only one association with predominance of AOM (70-95\%). According to the authors, the sedimentary succession presented 
anoxic-dysoxic conditions consistent with a shallow water column. Thus, their data are comparable to those identified at this stage.

During this phase, Botryococcus braunii colonies were the predominant palynomorphs, followed by colporate pollen grains (Fig. 4). Botryococcus braunii have worldwide distribution and occur in lakes, rivers and temporarily waterlogged areas, from the tropics to temperate and cold regions (Tyson 1995). This algal species is common in shallow-water environments with low rainfall and a distinctly seasonal climate (GuyOhlson 1992). Thus, the particulate organic matter data representative of phase 2 deposits are related to the establishment of an environment a bit deeper than the previous floodplain phase, probably representing a shallow lake. This interpretation can be confirmed by predominance of Botryococcus braunii and a trend of low $\mathrm{C} / \mathrm{N}$ values, indicating freshwater phytoplankton influence.

The variation in the amount of pollen grains in aquatic environments is based primarily on the flow rate of the deposition site, the amount of grains deposited on the surface of the water, and the flow velocity in tributaries (Bauermann et al. 2002). Some pollen will have entered the lake via inflowing streams and in flooding events, reflecting either local or regional vegetation, depending on the drainage area of these streams. Given the large size of the lake, wind-dispersed pollen entering this site likely reflects regionalscale vegetation.

The period between 7000 and $\sim 4000$ cal years BP for the region of Linhares was described by Buso Junior et al. (2013a) as being humid due to the increasing summer insolation and increasing summer monsoons (Cruz Jr et al. 2005). According to the authors, the modern seasonal climate was established from 4000 cal years BP, when summer insolation was similar to present and the Intertropical Convergence Zone (ITCZ) migrated southward. Based on these data, Lake Canto Grande was established under a climate similar and/or comparable to today's (Fig. 8).

The Neogene plateau where Lake Canto Grande is located is characterized by broad valleys with flat bottoms clogged by Quaternary sediments and, to a lesser extent, traversed by streams (Suguio et al. 1982). According to Suguio and Kohler (1992), most lakes in the studied region were formed through damming of river courses by marine or fluvial sediments. Valley excavation probably occurred during the last glaciation maximum (21,000-18,000 years B.P.), and were subsequently filled with fluvial sediments (Suguio and Kohler 1992). Favored by the drop in base level during the previous phase, the drainage network that had settled in the Pleistocene terraces was 
1 flooded during the Holocene transgression, which reached its maximum at 5,000 years

2 B.P. (Angulo et al. 2006). Associated with this transgression, barrier islands developed,

3 which isolated Pleistocene marine terraces from direct contact with the sea, allowing the

4 formation of lagoons behind these islands (Dominguez et al. 1981).

Recent studies in the region have shown the development of beach ridge systems

6 by dispersion of sands from the Doce River Delta, resulting in the transformation of the

7 estuaries into lakes (Buso Junior et al. 2013b; Castro et al. 2013; Lorente et al. 2014;

8 Rossetti et al. 2015). Similarly, Cohen et al. (2014) and França et al. (2015) recorded mangroves in the region during the Middle to Late Holocene, which reflect a transitional environment and marine influence. However, particulate organic matter data did not record this transgressive event. Similarly, Nascimento (2012) also did not find any microfossil evidence for marine influence in either Lake Juparanã or Lake Durão, lakes close $\sim 16 \mathrm{~km}$ and $\sim 3 \mathrm{~km}$, respectively, to Lake Canto Grande. A possible explanation for this disparity is that the Pleistocene beach ridge may have acted as a barrier to marine transgression. In this way, the Lake Canto Grande formation did not have marine influence and its evolution could be related similarly with Doce River Middle Valley lakes, where due to dry climate (less humid) in Early Holocene the mouths of river's tributaries were obstructed by sediments and the lakes were completely filled with water during periods of wet climate (Suguio and Kohler 1992).

According to the geomorphological characteristics and the distribution of lakes across the Doce River region and the coastal plain, Hatushika et al. (2007) divided the lakes of the region into two groups: i) inland lakes (Lake Juparanã) that are embedded in the Barreiras Formation and northern bank of the Doce River, and ii) external lakes (Lake Durão, Lake Canto Grande) which are situated at the boundary between the Neogene plateau and Quaternary coastal plain. In a seismo-stratigraphic study at Lake Juparanã, Hatushika et al. (2007) identified 20 m of Holocene fluvial sediments (seismo-sequence A) that probably began deposition at the end of the Pleistocene transgression. Lake sediments (seismo-sequence B) would have been deposited from $\sim 7,000$ years B.P. as a result of fluvial valley damming (Hatushika et al. 2007). The floodplain deposits of phase 1 recorded in Lake Canto Grande can be correlated with the seismo-sequence A identified for Lake Juparanã, with the occurrence of alluvial sediments. Similarly, sediments from phase 2 are comparable with their seismo-sequence B. Santos (2009) identified similar seismo-sequences in Lake Durão. He also observed a seismo-sequence associated with 
1 Pleistocene sand bars, and suggested that they were excavated by the lake paleo-drainage, implying that the formation of the sand bar pre-dates lake formation.

Regarding the process of lake formation on the Neogene plateau, Hatushika et al. (2007) and Santos (2009) proposed changes in relative sea level and tectonic movements during the Holocene as responsible for lake damming. Similar data were described for the middle valley region of the Doce River, where lakes were formed by tectonic movements (Mello et al. 1999). Silva et al. (2010) described the components of the particulate organic matter from Lake Preta in the middle valley of Doce River and also considered tectonic events in the lake formation.

The margins of the lake deposits of the Barreiras Formation are oriented in a NWSE direction, and several of them are marked by faults correlating with the drainage patterns (Hatushika et al. 2007). The accumulation of lake sediments in different depocenters of Lake Juparanã also suggested that Holocene tectonic movements affected sedimentary deposition, resulting in geologic tilting of the ancient river valley (Hatushika et al. 2007). Although few studies of tectonic movements have been published for the region, tectonics can be considered as a significant driver in the evolution of Lake Canto Grande.

\section{Conclusions}

This work allowed us to characterize the particulate organic matter from a Holocene lake in southeast Brazil and provide new insights about Doce River lower course evolution. Particulate organic matter of lakes in combination with stable $\mathrm{C}$ and $\mathrm{N}$ isotopes demonstrated being useful for paleoreconstruction in Quaternary, mainly focusing on marine and/or terrestrial influence in the basin. During $~ 10,943$ cal yr. B.P and $\sim 8,529 \mathrm{cal}$ yr. B.P. the basin may have been a floodplain characterized by periodic flooding and influx of terrigenous material recorded by predominance of amorphous organic matter, abundance of riverine elements (non-opaque and opaque phytoclasts), and sandy sediments interspersed with mud. After $\sim 8,529 \mathrm{cal}$ yr. B.P. the establishment of the lake under environmental conditions similar to those of the present-day occurred. Particulate organic matter showed the predominance of amorphous organic matter, palynomorphs, and high TOC values revealing a depositional environment of low turbulence and dysoxic-anoxic conditions at the water-sediment interface. 
No marine evidence was recorded in the sedimentary deposit, and thus, changes in relative sea level during the Holocene did not directly influence the evolution of the lake as seen in other studies that have been published for the region. Lake Canto Grande evolved similarly to the lakes of Doce River Middle Valley, where climatic changes and tectonics mechanisms were the main forcing factors.

\section{Acknowledgements} 2010/52606-1 and 2011/00995-7) and Conselho Nacional de Desenvolvimento Científico e Tecnológico - CNPq (grants 470210/2012-5, 245572/2012-0 and 405060/2013-0) for financial support. We also thank the Vale Nature Reserve (Linhares, Brazil) for supporting the field work and the technician Thiago Campos from the ${ }^{14} \mathrm{C}$ Laboratory of CENA-USP for his help with sample preparation for AMS radiocarbon dating. We also wish to thank the editors, P.A. Meyers, S. Grill and an anonymous reviewer for their remarks to improve this manuscript.

\section{References}

Angulo, R.J., Lessa, G.C., Souza, M.C. de., 2006. A critical review of mid- to lateHolocene sea-level fluctuations on the eastern Brazilian coastline. Quaternary Science Review, 25, 486-506.

Batten, D.J., 1996. Palynofacies and palaeoenvironmental interpretation. In: Jansonius, J., McGregor, D.C. (Eds.), Palynology: principles and applications. American Association Stratigraphic Palynologists Foundation, Dallas, 1011-1064.

Bauermann, S.G., Marques-Toigo, M., Behling, H., Neves, P.C.P. das., 2002. Aspectos tafonômicos em palinologia de Quaternário. Pesquisas Série Botânica, 52, 223-239.

Boussafir, M., Sifeddine, A., Jacob, J., Foudi, M., Cordeiro, R.C., Albuquerque, A.L.S., Abrao, J.J., Turcq, B., 2012. Petrographical and geochemical study of modern lacustrine sedimentar organic matter (Lagoa do Caçó, Maranhão, Brazil): relationship between early diagenesis, organic sedimentation and lacustrine filling. Organic Geochemistry, 47, 88-98. 
1 Boutton, T.W., 1996. Stable carbon isotope ratios of soil organic matter and their use as indicators of vegetation and climate change. In: Boutton, T.W., Yamasaki, S. (Eds.), Mass spectrometry of soils. Mercel Dekker, New York, 47-82.

Bridge, J.S., 2006. Fluvial facies models: recent developments. In: Posamentier, H.W., Walker, R.G. (Eds.), Facies models revisited. Society for Sedimentary Geology, Tulsa, 85-170.

Buso Junior, A.A., Pessenda, L.C.R., De Oliveira, P.E., Cohen, M.C.L., Giannini, P.C.F., Schiavo, J.A., Rossetti, D.F., Volkmer-Ribeiro, C., Oliveira, S.M.B., Lorente, F.L., Borotti Filho, M.A., Bendassolli, J.A., Siqueira, J.S., 2013a. Late Pleistocene and Holocene vegetation and climate dynamics and Amazonian taxa at Atlantic Rainforest - Linhares, ES, southeastern Brazil. Radiocarbon, 55, 1747-1762.

Buso Junior, A.A., Pessenda, L.C.R., De Oliveira, P.E., Giannini, P.C.F., Cohen, M.C.L., Volkmer-Ribeiro, C., Oliveira, S.M.B., Favaro, D.I.T., Rossetti, D.F., Lorente, F.L., Borotti Filho, M.A., Schiavo, J.A., Bendassolli, J.A., França, M.C., Guimarães, J.T.F., 2013b. From na estuary to a freshwater lake: a paleo-estuary evolution in the context of Holocene sea-level fluctuations, SE Brazil. Radiocarbon, 55, 1735-1746

Buso Junior, A.A., 2015. Dinâmica dos espodossolos, da vegetação e do clima durante o Quaternário tardio na região nordeste do estado do Espírito Santo. Ph.D. thesis, University of São Paulo.

Camargo, M.G. de., 1999. SYSGRAN: um sistema de código aberto para análises granulométricas do sedimento. Revista Brasileira de Geociências, 36, 371-378.

Castro, D.F., Rossetti, D.F., Cohen, M.C,. Pessenda, L.C.R., Lorente, F.L., 2013. The growth of the Doce River Delta in northeastern Brazil indicated by sedimentary facies and diatoms. Diatom Research, 28, 455-466.

Cohen, A.S., 2003. Paleolimnology: The history and evolution of lake systems. Oxford University Press, New York.

Cohen, M.C.L., França, M.C., Rossetti, D.F., Pessenda, L.C.R., Giannini, P.C.F., Lorente, F.L., Buso Junior, A.A., Castro, D., Macario, K., 2014. Landscape evolution during the late Quaternary at the Doce River mouth, Espírito Santo State, southeastern Brazil. Palaeogeography, Palaeoclimatology, Palaeoecology, 415, 48-58.

Colinvaux, P., De Oliveira, P.E., Patiño, J.E.M., 1999. Amazon pollen manual and atlas. Harwood Academic Publications, Amsterdam.

Combaz, A., 1964. Les palynofacies. Revue de Micropaléontologie, 7, 205-218. 
1 Cruz Jr, F.W., Burns, S.J., Karmann, I., Sharp, W.D., Vuille, M., Cardoso, A.O., Ferrari, J.A., Dias, P.L.S., Viana, Jr O., 2005. Insolation-driven changes in atmospheric circulation over the past 116,000 years in subtropical Brazil. Nature, 434, 63-66.

Dominguez, J.M.L., Bittencourt, A.C.S.P., Martin, L., 1981. Esquema evolutivo da sedimentação quaternária nas feições deltaicas dos rios São Francisco (SE/AL), Jequitinhonha (BA), Doce (ES) e Paraíba do Sul (RJ). Revista Brasileira de Geociências, 11, 227-237.

Esteves, F.A., 1988. Fundamentos de Limnologia. Editora Interciência, Rio de Janeiro. França, M.C., Alves, I.C.C., Castro, D.F., Cohen, M.C.L., Rossetti, D.F., Pessenda, L.C.R., Lorente, F.L., Fontes, N.A., Buso Junior, A.A., Giannini, P.C.F., Francisquini, M.I., 2015. A multi-proxy evidence for the transition from estuarine mangroves to deltaic freshwater marshes, southeastern Brazil, due to climatic and sea-level changes during the late Holocene. Catena, 128, 155-166.

Gadens-Marcon, G.T., Guerra-Sommer, M., Mendonça-Filho, J.G., 2014. Palynofacies and organic geochemistry studies of organic matter from a wetland system of southern Brazil influenced by different hydrological regimes in the Quaternary. Journal of South America Earth Sciences, 56, 41-53.

Grill, S., Borromei, A.M., Quattrocchio, M., Coronato, A., Bujalesky, G., Rabassa, J., 2002. Palynological and sedimentological analysis of recent sediments from Rio Varela, Beagle channel, Tierra del Fuego, Argentina. Revista Española de Micropaleontologia, 34, 145-161.

Grill, S., Borromei, A., Martínez, G., Gutierrez, M.A., Cornou, M.E., Oliveira, D., 2007. Palynofacial analysis in alcaline soils and paleoenvironmental implications: The Paso Otero 5 archaeological site (Necochea district, Buenos Aires province, Argentina). Journal of South America Earth Sciences, 24, 34-47.

Grimm, E.C., 1987. CONISS: a fortram 77 program for stratigraphically constrained cluster analysis by the method of the incremental sum of squares. Computer Geosciences, 13, 13-35.

Guy-Ohlson, D., 1992. Botryococcus as an aid in the interpretation of palaeoenvironment and depositional processes. Review Palaeobotany Palynology, 71, 1-15.

Hatushika, R.S., Silva, C.G., Mello, C.L., 2007. Sismoestratigrafia de alta resolução no Lago Juparanã, Linhares (ES-Brasil) como base para estudos sobre a sedimentação e tectônica quaternária. Revista Brasileira Geofísica, 25, 433-442. 
1 IBGE - Instituto Brasileiro de Geografia e Estatística., 1987. Carta do Brasil, Folha SE-

24 Rio Doce: geologia, geomorfologia, pedologia, vegetação, uso potencial da terra. Rio IBGE, Rio de Janeiro.

Köppen, W., 1948. Climatologia: con un studio de los climas de la tierra. Fondo de Cultura Econômica, Ciudad del Mexico.

Lehmann, M.F., Bernasconi, S.M., Barbieri, A., McKenzie, J.A., 2002. Preservation of organic matter and alteration of its carbono and nitrogen isotope composition during simulated and in situ early sedimentar diagenesis. Geochimica Cosmochimica Acta, $66,3573-3584$.

Livingstone, D.A., 1955. A lightweight piston sampler for lake deposits. Ecology, 36, 137-139.

Lorente, F.L., Pessenda, L.C.R., Oboh-Ikuenobe, F.E., Buso Junior, A.A., Cohen, M.C.L., Meyer, K.E.B., Giannini, P.C.F., De Oliveira, P.E., Rossetti, D.F., Borotti Filho, M.A., França, M.C., Castro, D.F., Bendassolli, J.A., Macario, K., 2014. Palynofacies and stable $\mathrm{C}$ and $\mathrm{N}$ isotopes of Holocene sediments from Lake Macuco (Linhares, Espírito Santo, southeastern Brazil): depositional settings and palaeoenvironmental evolution. Palaeogeography, Palaeoclimatology, Palaeoecology, $415,69-82$.

Martin, L., Suguio, K., Flexor, J.M., 1993. As flutuações de nível do mar durante o Quaternário superior e a evolução geológica de “deltas” brasileiros. Boletim IG-USP, $15,1-196$.

Mello, C.L., Metelo, C.M.S., Suguio, K., Kohler, H.C., 1999. Quaternary sedimentation, neotectonics and the evolution of the Doce River middle valley lake system (southeastern Brazil). Revista Instituto Geociências, 20, 29-36.

Mendonça Filho, J.G., 1999. Aplicação de estudos de palinofácies e fácies orgânica em rochas do Paleozóico da Bacia do Paraná, Sul do Brasil. PhD thesis, Federal University of Rio Grande do Sul.

Mendonça Filho, J.G., Chagas, R.B.A., Menezes, T.R., Mendonça, J.O., Silva, F.S. da., Sabadini-Santos, E., 2010. Organic facies of the Oligocene lacustrine system in the Cenozoic Taubaté basin, Southern Brazil. International Journal of Coal Geology, 84, 166-178.

Menezes, T.R., Mendonça Filho, J.G., Araujo, C.V., Souza, I.V.A.F de., Mendonça, J.O., 2008. Fácies orgânica: conceitos, métodos e estudos de casos na indústria do petróleo. Revista Brasileira de Geociências, 38, 80-96. 
Meyer, K.E.B., Mendonça Filho, J.G., Ashraf, A.R., Souza, P.A. de., Reichhart, K., 2005. Análise de palinofácies em sedimentos holocênicos da Lagoa dos Quadros, Rio Grande do Sul, Brasil. Revista Brasileira de Paleontologia, 8, 57-72.

Meyers, P.A., 1997. Organic geochemical proxies of paleoceanographic, paleolimnologic, and paleoclimatic processes. Organic Geochemistry, 27, 213-250.

Meyers, P.A., 2003. Applications of organic geochemistry to paleolimnological reconstructions: a summary of examples from the Laurentian Great Lakes. Organic Geochemistry, 34, 261-289.

Meyers, P.A., Lallier-Vergès, E., 1999. Lacustrine sedimentary organic matter records of Late Quaternary paleoclimates. Journal Paleolimnology, 21,345-372.

Moreira, L.S., Moreira-Turcq, P., Turcq, B., Cordeiro, R.C., Kim, J-H., Caquineau, S., Mandeng-Yogo, M., Macario, K., Damsté, J.S.S., 2013. Palaeohydrological controls on sedimentary organic matter in an Amazon floodplain lake, Lake Maracá (Brazil) during the late Holocene. The Holocene, 23, 1903-1914.

Moreira-Turcq, P., Bonnet, M-P., Amorim, M., Bernardes, M., Lagane, C., Maurice, L., Perez, M., Seyler, P., 2013. Seasonal variability in concentration, composition, age, and fluxes of particulate organic carbon exchanged between the floodplain and Amazon River. Global Biogeochemistry Cycles, 27, 119-130.

Nascimento, T.C., 2012. Reconstituição da história quaternária da Mata Atlântica na região Centro-Norte do estado do Espírito Santo. Master dissertation, University of Guarulhos.

Oboh, F.E., 1992. Palynodebris from the Middle Miocene of the Niger Delta and their environmental significance. Palaios, 7, 559-573.

Ogrinc, N., Fontolan, G., Faganeli, J., Covelli, S., 2005. Carbon and nitrogen isotope compositions of organic matter in coastal marine sediments (the Gulf of Trieste, $\mathrm{N}$ Adriatic Sea): indicators of sources and preservation. Marine Chemistry, 95, 163-181.

Pessenda, L.C.R., Gouveia, S.E.M., Aravena, R., Boulet, R., Valencia, E.P.E., 2004. Holocene fire and vegetation changes in southeastern Brazil as deduced from fossil charcoal and soil carbon isotopes. Quaternary International, 114, 35-43.

Reimer, P.J., Baillie, M.G.L., Bard, E., Bayliss, A., Beck, J.W., Blackwell, P.G., Bronk Ramsey, C., Buck, C.E., Burr, G.S., Edwards, R.L., Friedrich, M., Grootes, P.M., Guilderson, T.P., Hajdas, I., Heaton, T.J., Hogg, A.G., Hughen, K.A., Kaiser, K.F., Kromer, B., McCormac, F.G., Manning, S.W., Reimer, R.W., Richards, D.A., Southon, J.R., Talamo, S., Turney, C.S.M., Van der Plicht, J., Weyhenmeyer, C.E., 
2009. Intcal09 and Marine09 radiocarbon age calibration curves, 0-50,000 years cal BP. Radiocarbon, 51, 1111-1150.

Rossetti, D.F., Polizel, S.P., Cohen, M.C.L., Pessenda, L.C.R., 2015. Late PleistoceneHolocene evolution of the Doce River delta, southeastern Brazil: implications for the understanding of wave-influenced deltas. Marine Geology, 367, 171-190.

Ruttenberg, K.C., Goñi, M.A., 1997. Phosphorus distribution, C:N:P ratios, and $\delta 13 C$ in arctic, temperate, and tropical coastal sediments: tools for characterizing bulk sedimentary organic matter. Marine Geology, 139, 123-145.

Santos, F.F.V., 2009. Investigação Sismoestratigráfica na lagoa Durão - Sistema de lagos do Baixo Curso do Rio Doce, Linhares (ES). Graduation student term paper, Federal University of Rio de Janeiro.

Scherer, C.M.S., 2008. Ambientes fluviais. In: Silva, A.J.C.L.P., Aragão, M.A.N.F., Magalhães, A.J.C. (Eds.), Ambientes de sedimentação siliciclástica do Brasil. Beca/BALL, São Paulo, 102-130.

Sebag, D., Di-Giovanni, C., Ogier, S., Mesnage, V., Laggoun-Défarge, F., Durand, A., 2006a. Inventory of sedimentary organic matter in modern wetland (Marais Vernier, Normandy, France) as source-indicative tools to study Holocene alluvial deposits (Lower Seine Valley, France). International Journal Coal Geology, 67, 1-16.

Sebag, D., Copard, Y., Di-Giovanni, C., Durand, A., Laignel, B., Ogier, S., LallierVerges, E., 2006b. Palynofacies as useful tool to study origins and transfers of particulate organic matter in recent terrestrial environments: synopsis and prospects. Earth-Science Review, 79, 241-259.

Shepard, F.P., 1954. Nomenclature based on sand-silt-clay ratios. Journal of Sedimentary Petrology, 24, 151-158.

Silva, Y.M.P., Meyer, K.E.B., Peronico, C., Castro, P.de.T.A., 2010. Palinofácies de uma seqüência sedimentar quaternária da Lagoa Preta, Parque Estadual do Rio Doce, MG, Brasil. Revista Brasileira de Paleontologia, 13, 49-56.

Suguio, K., Martin, L., Dominguez, J.M.L., 1982. Evolução da planície costeira do Rio Doce (ES) durante o Quaternário: influência das flutuações do nível do mar. Atas do IV Simpósio do Quaternário do Brasil 1, 93-116.

Suguio, K., Kohler, H.C., 1992. Quaternary barred lake systems of the Doce River (Brazil). Anais da Academia Brasileira de Ciências, 64, 182-191. 
1 Talbot, M., Johannessen, T., 1992. A high resolution palaeoclimatic record for the last

2

3

4 27,500 years in tropical West Africa from the carbon and nitrogen isotopic composition of lacustrine organic matter. Earth Planet Science Letters, 110, 23-37.

Tyson, R.V., 1995. Sedimentary organic matter: organic facies and palynofacies. Chapman \& Hall, London.

Vieira, R.A.B., Mendes, M.P., Vieira, P.E., Costa, L.A.R., Tagliari, C.V., Bacelar, L.A.P., Feijó, F.J., 1994. Bacias do Espírito Santo e Mucuri. Boletim de Geociências da Petrobrás, 8, 195-202.

Zocatelli, R., Turcq, B., Boussafir, M., Cordeiro, R.C., Disnar, J.R., Costa, R.L., Sifeddine, A., Albuquerque, A.L.S., Bernardes, M.C., Jacob, J., 2012. Late Holocene paleoenvironmental changes in Northeast Brazil recorded by organic matter in lacustrine sediments of Lake Boqueirão. Palaeogeography, Palaeoclimatology Palaeoecology, 363-364, 127-134.

Wentworth, C.K., 1922. A scale of grade and class terms for clastic sediments. Journal of Geology, 30, 377-392.

Wolman, M.G., Leopold, L.B., 1957. River flood plains: some observations on their formation. U.S Geological Survey Professional Paper, 282-C, 87-107. 
1 Figure captions

2

3 Fig. 1 Location of the study area. $a-b$ Study area images. The star indicates the location

4 where the core was sampled in the Lake Canto Grande. $c$ Modern photograph of Lake

5 Canto Grande

6

7 Fig. 2 Stratigraphy and granulometry of LCG-B core and Shepard's diagram with the

8 sedimentary samples distribution (modified from Shepard 1954)

9

10 Fig. $3{ }^{14} \mathrm{C}$ ages, stratigraphy, total organic carbon (TOC), $\delta^{13} \mathrm{C}$, total nitrogen (TN), $\delta^{15} \mathrm{~N}$ and $\mathrm{C} / \mathrm{N}$ values (weight/weight)

Fig. 4 Relative frequencies of particulate organic matter components. AOM: amorphous organic matter. OP: opaque phytoclasts. NOP: non-opaque phytoclasts. PAL: palynomorphs

Fig. $5 a \delta^{13} \mathrm{C}$ vs. $\mathrm{C} / \mathrm{N}$ values (weight/weight) of Lake Canto Grande organic matter. Interpretation was based according to data presented by Meyers (1997) and Ogrinc et al. (2005)

Fig. 6 Relative frequencies of major particulate organic matter components and total organic carbon (TOC), $\delta^{13} \mathrm{C}$, total nitrogen $(\mathrm{TN}), \delta^{15} \mathrm{~N}$ and $\mathrm{C} / \mathrm{N}$ values (weight/weight). AOM: amorphous organic matter. NOP: non-opaque phytoclasts. OP: opaque phytoclasts. PAL: palynomorphs

Fig. 7 Values of TOC and TN for Lake Canto Grande samples and their respective linear regression lines. Samples from 135 to $105 \mathrm{~cm}$ are indicated by light circles and samples from 103 to $1 \mathrm{~cm}$ are indicated by dark circles. The arrows indicate the samples that were not used in the regression analyzes

Fig. 8 Model of paleoenvironmental changes in the study area during the Holocene. Sealevel changes were expressed in the figure according to previous studies in the region (Castro et al. 2013; Lorente et al. 2014; França et al. 2015) 


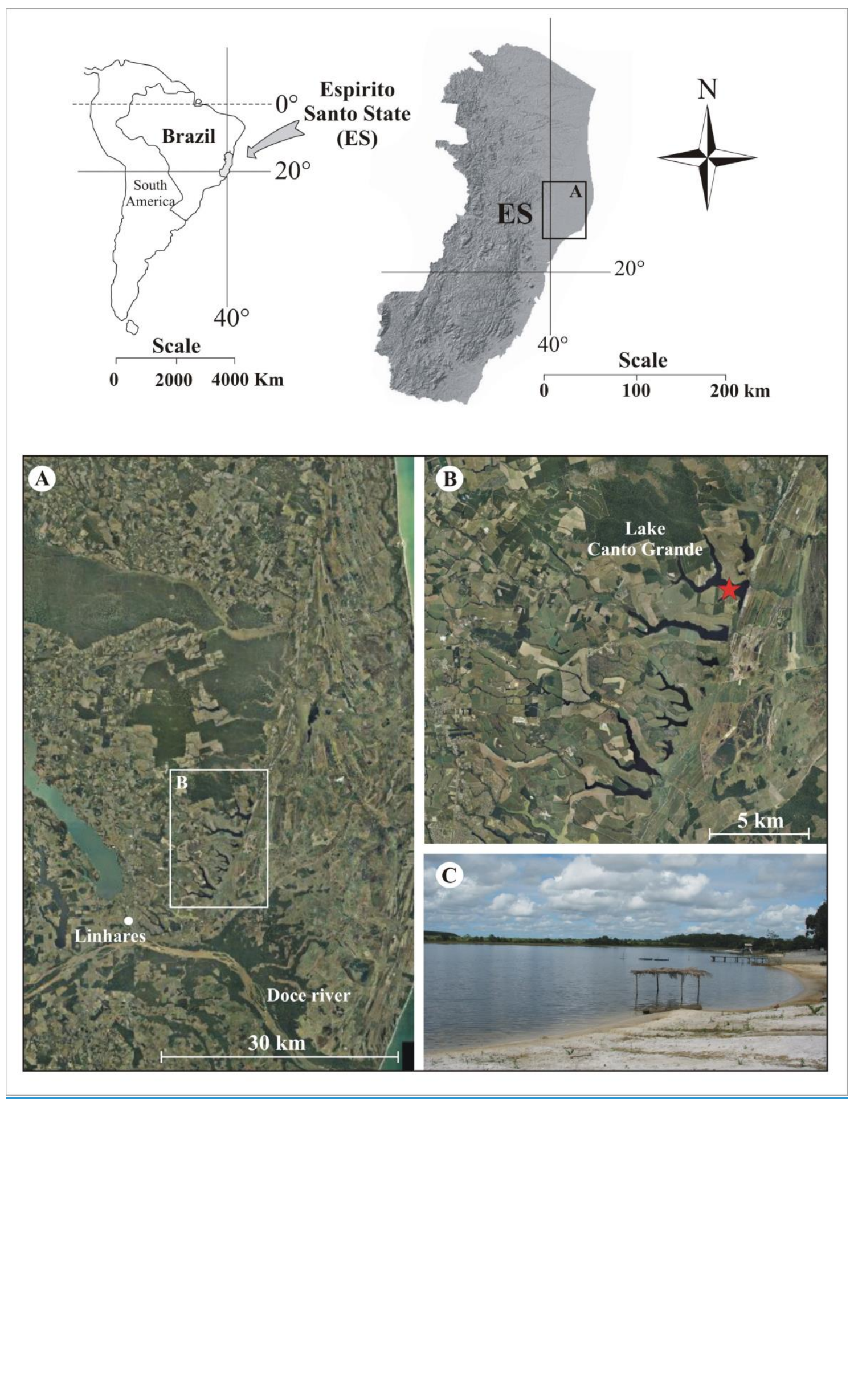




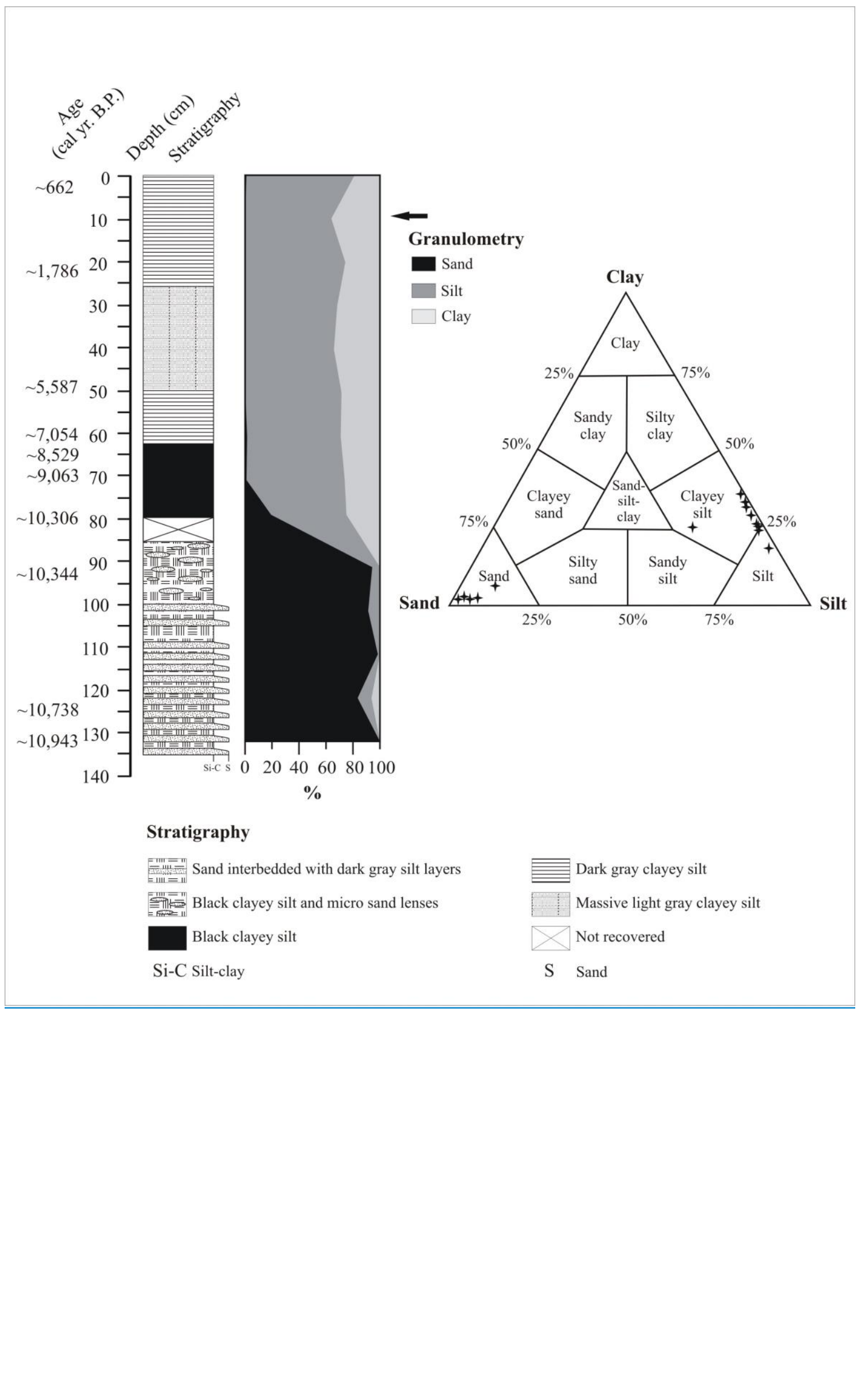




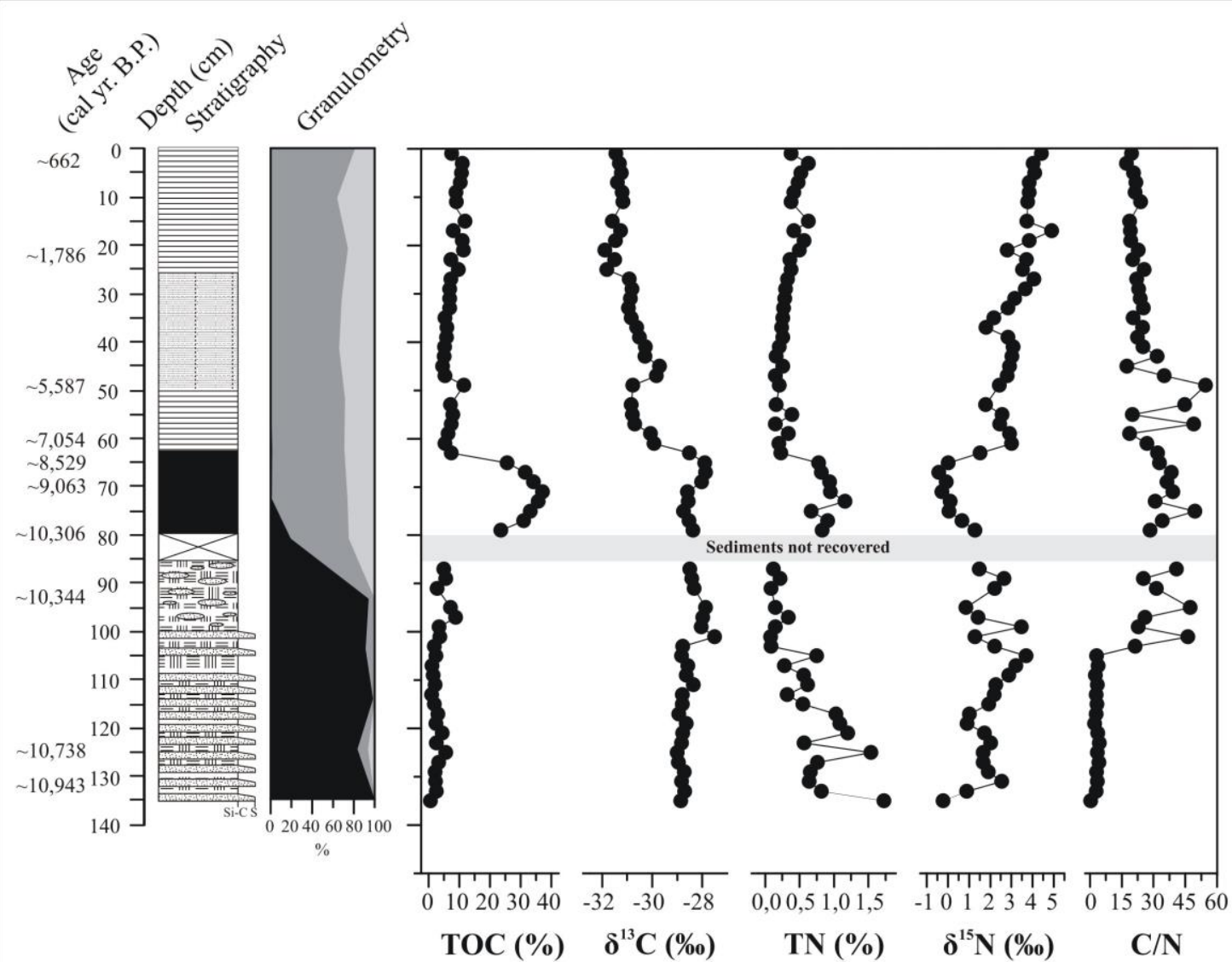

Granulometry Stratigraphy

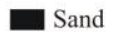

Silt

$\square$ Clay
피를

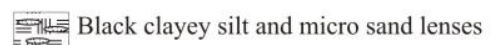

Black clayey silt

Si-C Silt-clay

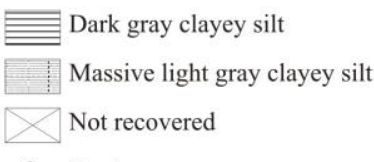

S Sand
1

2

3

4

5

6

7

8

9

10

11

12

13 


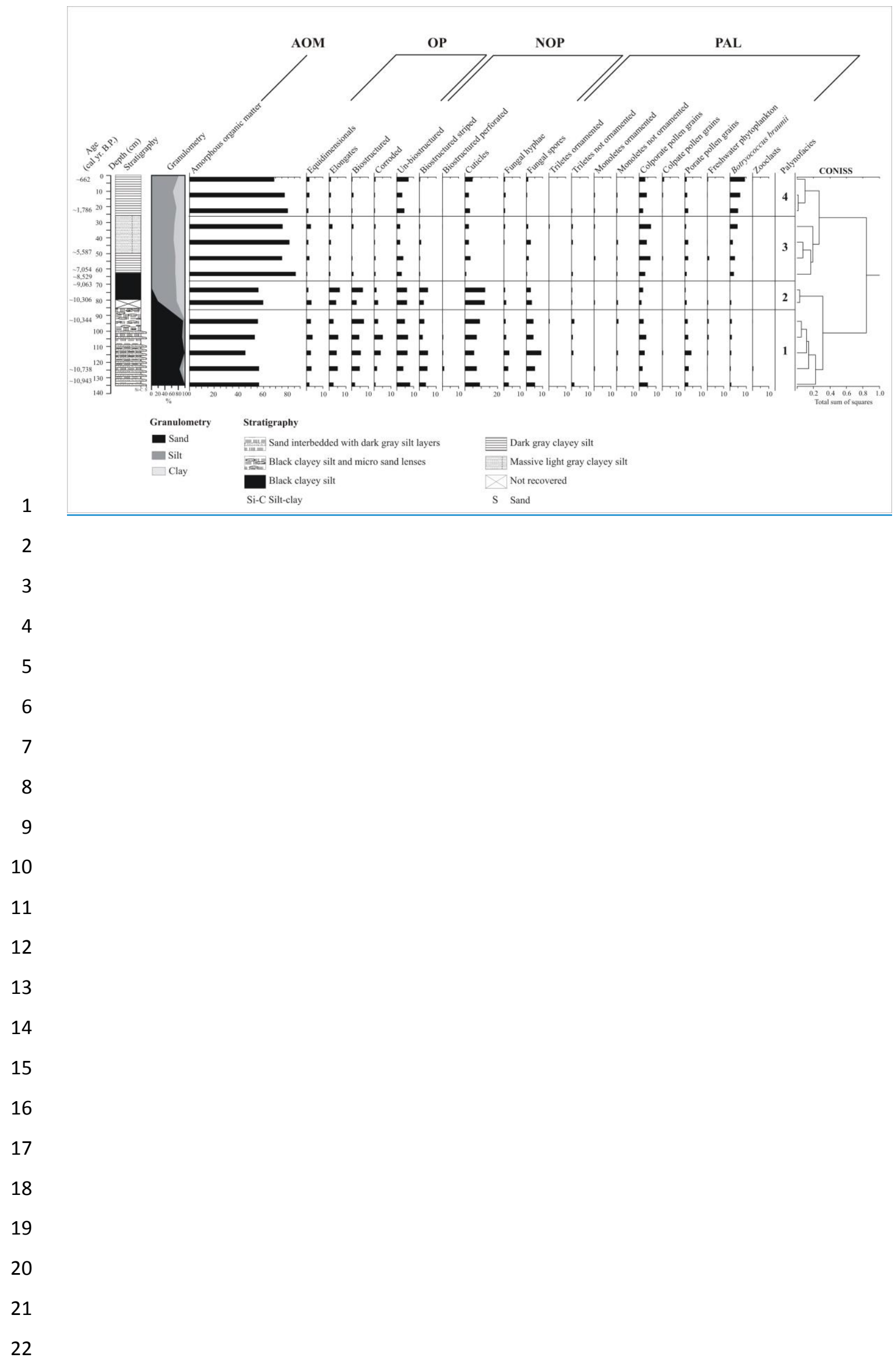




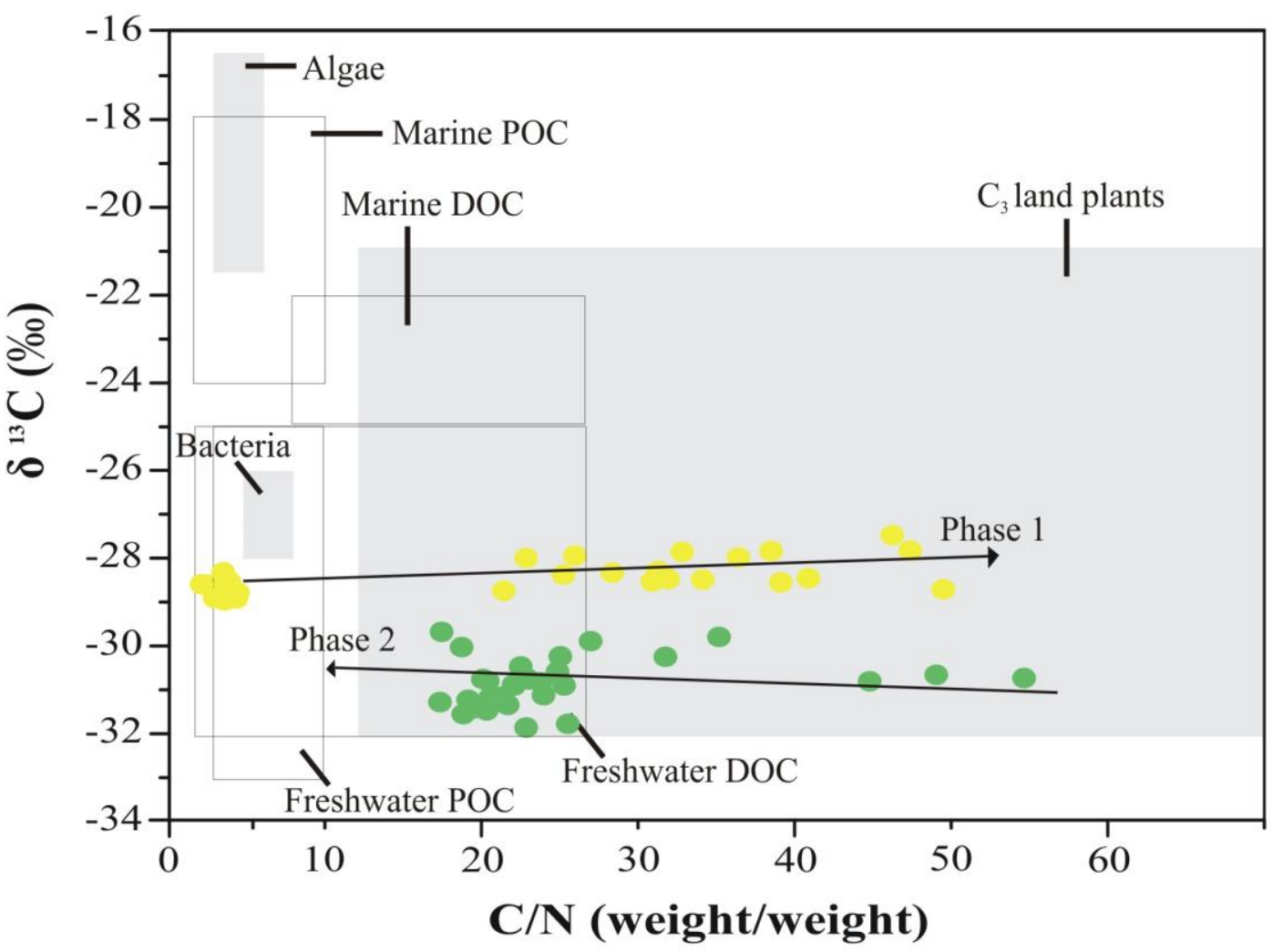

1

2

3

4

5

6

7

8

9

10

11

12

13

14

15

16

17

18 


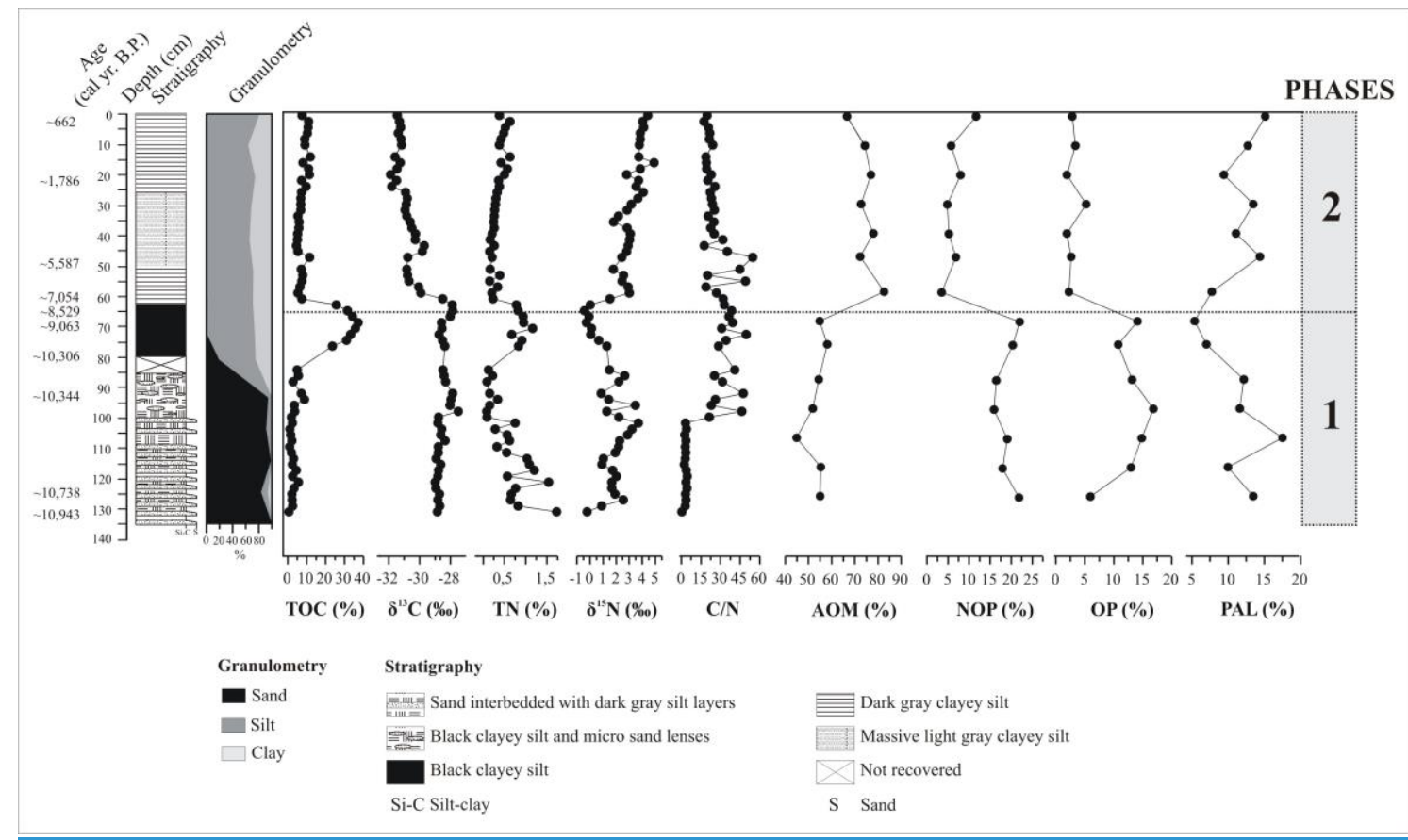

1

3

4

5

6

7

8

9

10

11

12

13

14

15

16

17

18

19

20

21 


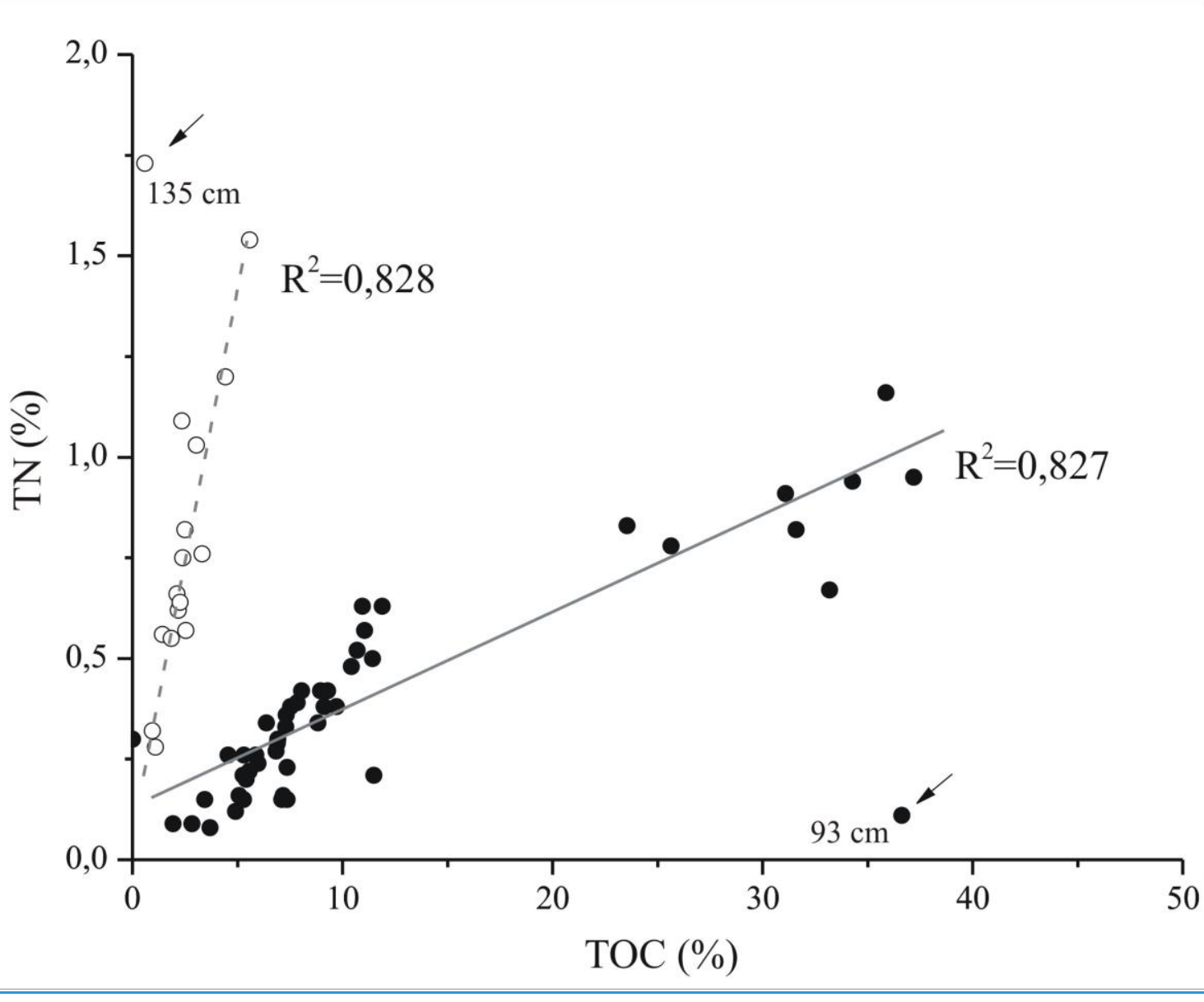

2

3

4

5

6

7

8

9

10

11

12

13

14

15

16

17 


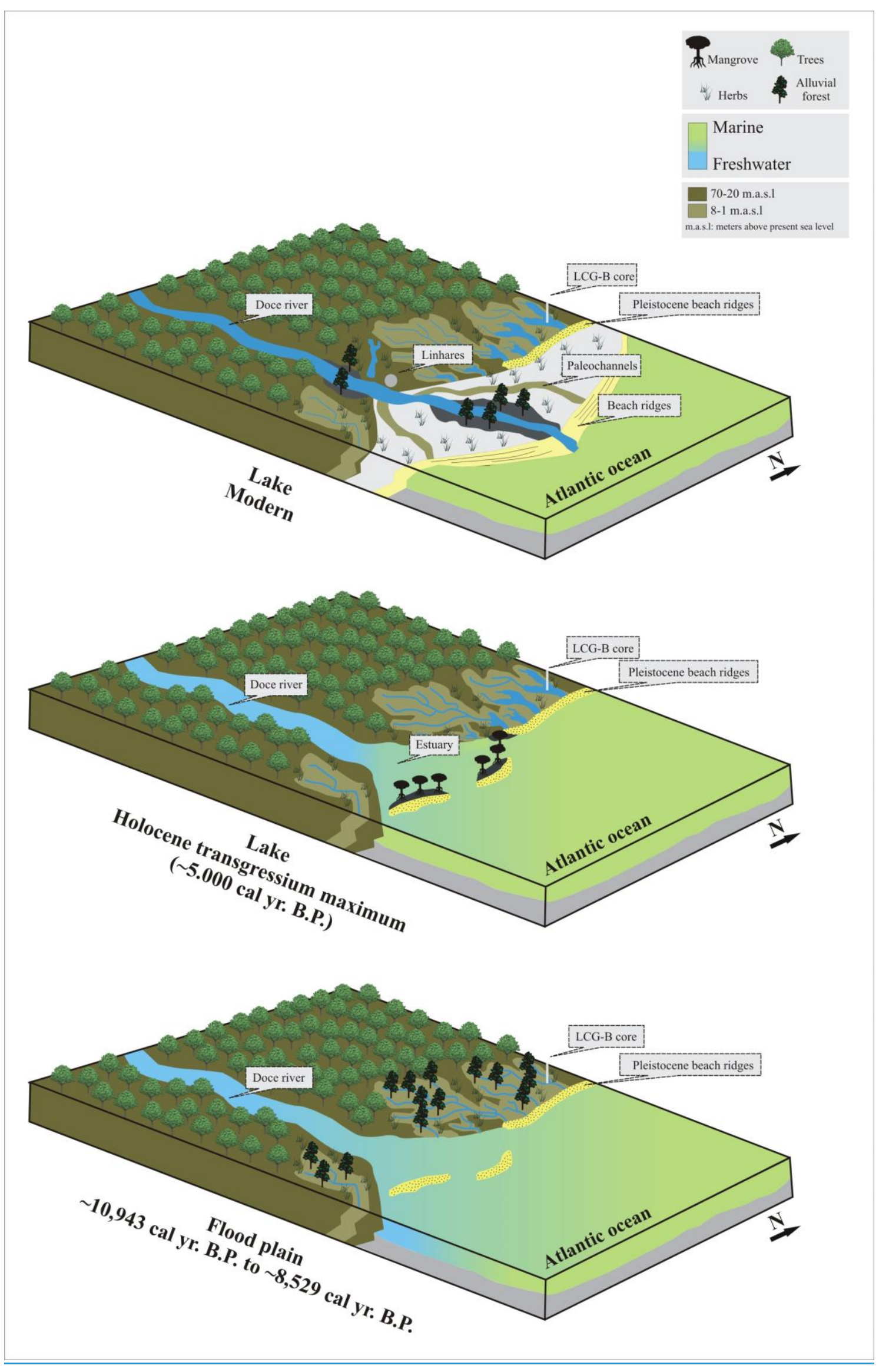

